\title{
Contribution of Home and School Environment in Children's Food Choice and Overweight/Obesity Prevalence in African Context: Evidence for Creating Enabling Healthful Food Environment
}

This article was published in the following Dove Press journal:

Pediatric Health, Medicine and Therapeutics

\author{
Renatha Pacific (D) ${ }^{1,2}$ \\ Haikael D Martin' \\ Kissa Kulwa ${ }^{2}$ \\ Pammla Petrucka ${ }^{3}$ \\ 'Department of Food Biotechnology and \\ Nutrition Sciences, Nelson Mandela \\ African Institution of Science and \\ Technology, Arusha, Tanzania; \\ ${ }^{2}$ Department of Food Technology, \\ Nutrition and Consumer Sciences, \\ Sokoine University of Agriculture, \\ Morogoro, Tanzania; ${ }^{3}$ College of Nursing, \\ University of Saskatchewan, Regina, SK, \\ Canada
}

\begin{abstract}
This review aimed primarily to investigate the current trends of overweight and obesity in school children in the African context, secondly to explore the contribution of home and school environments on the children's food choices and lastly suggesting measures for creating a healthier food environment. Despite the increase in overweight and obesity among school children, empirical evidence on their determinants in the African context is scarce, thus calls for consideration of home and school environments. A literature search was conducted between October and December 2018 using Medline (PubMed), Directory of Open Access Journals, Google Scholar, manual search and "grey" literature. This review included articles published between the 1st January 2008 and 30th June 2018. Out of 343 articles, 49 were included for the full text reading after meeting the inclusion criteria. Five reports from grey literature were also included. Results show that the prevalence of overweight and obesity among school children in Africa is increasing and ranges from $<5 \%$ to $>40 \%$ in the 10 -year period in which the review was taken. High socio-economic status, urban residence and female gender predicted higher prevalence of overweight/obesity. Few reviewed articles on the contribution of home and school environments on children's food choices showed a shred of evidence, thus calls for further research to address this gap. This review found an increasing prevalence of overweight and obesity in school children in Africa. Therefore, further investigation of home and school environment is imperative to curb the increase in the magnitude of overweight and obesity.
\end{abstract}

Keywords: food choice, food environment, prevalence, school-children, strategies, Africa

\section{Introduction}

In recent decades fast increase in the prevalence of obesity and non-communicable diseases is evident in urban areas of low and middle-income countries. ${ }^{1-4}$ Overweight and/or obesity is referred as excess accumulation of fat in the body which is a precursor for non-communicable diseases. ${ }^{5-8}$ According to the International Obesity Task Force overweight in children is defined as a value between 85 th and 95th percentile, while obesity is a value above 95th percentile. ${ }^{102}$ World Health Organization has defined childhood overweight (5-19 years), as a value of +1 standard deviation (SD) which is equivalent to $25 \mathrm{~kg} / \mathrm{m}^{2}$ cut-off for adults and a value of +2 standard deviation $\left(29.7 \mathrm{~kg} / \mathrm{m}^{2}\right)$ as obesity which is close to adult's cut-off of $\left.\geq 30.0 \mathrm{~kg} / \mathrm{m}^{2}\right)^{103}$ Globally, there are about
Correspondence: Renatha Pacific Department of Food Biotechnology and Nutrition Sciences, Nelson Mandela

African Institution of Science and

Technology, P. O. Box 447, Arusha,

Tanzania

Tel +255759184316

Email pacificr@nm-aist.ac.tz 
42 million overweight children with over 35 million living in developing countries. ${ }^{9}$ In Africa, despite high levels of undernutrition, overweight and obesity rates in children are increasing, ${ }^{8}$ a pattern often attributed to limited policy support and lack of multi-sectoral collaboration. ${ }^{3}$ The 2018 Global Nutrition Report, showed that $4.6 \%$ of boys and $4.7 \%$ of girls (10-19 years) were obese globally. In Africa, for adolescent aged 10-19 years $2.5 \%$ of boys and $3.9 \%$ of girls were reported as obese in $2016 .{ }^{10}$

In sub-Saharan Africa, the prevalence of overweight and obesity is more than $10 \%$ in many countries such as; South Africa, Ethiopia, Cameroon, Nigeria, Kenya, and Tanzania (see Table 1). Several studies have reported a prevalence of more than $20 \%$ in childhood obesity across African nations (Table 1). A prevalence of more than $30 \%$ was reported in Uganda, and Egypt, whereas some studies in Zimbabwe, Tanzania and Sudan found a prevalence of less than $10 \%$ (see Table 1). Overweight and obesity in children have devastating physiological consequences, namely high cholesterol, and high blood pressure, high risk of impaired glucose tolerance, insulin resistance, type 2 diabetes, breathing problems and fatty liver disease, ${ }^{11,12}$ as well as psychosocial consequences, such as stigma, teasing, and harassment. ${ }^{1,13}$

The food environment across countries is in a state of rapid transformation due to changes in dietary patterns and food behaviors. ${ }^{14,15}$ The food environment is rooted in the recognition that an individual is surrounded by broad dimensions of obtaining and consuming food. It encompasses the extent to which someone accesses available food which is desirable and convenient, the way food is marketed, and exclusive properties of food, such as taste and appearance. ${ }^{16,17}$ Processed, convenient, and relatively low price foods are now readily available in many settings. ${ }^{18}$ Some studies ${ }^{2,19,20}$ reported that the school food environment contributes to children's food choices. Along with strong peer pressure, children feel forced to buy and consume these unhealthy food alternatives. ${ }^{20}$

School children and adolescents require adequate nutrient and energy inputs for growth, development, and good academic performance. ${ }^{21,22}$ Appropriate dietary choices and dietary intake are crucial for building good eating habits early in life. ${ }^{21,23}$ Eating habits during childhood may have long term implications; therefore, environments associated with children's food choices need to be studied for modification/reinforcement of healthy choices. Foods that are high in sugar and/or fat, which are globally available in school environments are associated with increased risk of obesity ${ }^{24}$ and their consumption is reported to increase at the highest rates ever. ${ }^{25,35}$

Escalating overweight and obesity rates in school children necessitate consideration of both home and school food environments as potential contributors. ${ }^{14,26}$ Children spend significant amounts of time in the school environment which may influence their food choices and shape their attitudes towards foods offered in the school. ${ }^{27}$ The home environment (through the physical presence of food and television advertisement) also influences children's food choices. ${ }^{28}$ Couch and colleagues ${ }^{29}$ reported that availability of unhealthy foods in the home has been associated with a lower intake of fruits and vegetables. Wang et $\mathrm{al}^{30}$ found that the home environment is responsible for shaping children's lifelong eating habits. At home, parents play a key role in children's exposure to foods. ${ }^{31}$

To the best of our knowledge, no review of the existing literature has investigated obesity prevalence and contributions of school and home environments in children's food choices in the African context. Therefore, the objectives of this review article were (i) to review the existing literature on current trends of overweight and obesity in Africa (ii) to determine the contribution of home and school environments to children's food choices and (iii) to suggest strategies for creating enabling healthy food environments for children.

\section{Methods}

\section{Search Strategy, Study Selection}

A systematic literature search was conducted for articles published on the prevalence of overweight and obesity in school children in Africa. Other articles searched were on the contribution of home and school environment in children's food choices. In addition, reports constituting "grey literature" on strategies for improving children's food environments were searched. A comprehensive keyword search was used for terms related to the topic of interest. We included original published articles conducted in Africa, human studies, reference age group (6-18 years) and within 10 years of publication. Studies done outside Africa, review articles and those which did not use the English language were excluded. A manual search via Google was also conducted from the reference lists of reviewed articles.

Three databases were included in this review: Medline (PubMed), Directory of Open Access Journals (DOAJ), 
Table I Summary of Evidence on Prevalence of Overweight and Obesity in School Children in Selected African Countries

\begin{tabular}{|c|c|c|c|c|c|c|}
\hline Author & Year & Country, Region & $\begin{array}{l}\text { Age } \\
\text { (Years }\end{array}$ & Study Design & $\begin{array}{l}\text { Sample } \\
\text { (n) }\end{array}$ & $\begin{array}{l}\text { Prevalence of Overweight/ } \\
\text { Obesity (\%) }\end{array}$ \\
\hline Pienaar ${ }^{3 a}$ & 2015 & South Africa, North-west & $6-9$ & Longitudinal & 574 & $\begin{array}{l}\text { OB I } 2.5 \text { baseline; } \\
\text { OB } 16.6 \text { follow-up }\end{array}$ \\
\hline $\begin{array}{l}\text { Baard \& } \\
\text { McKersie }\end{array}$ & 2014 & South Africa, Port Elizabeth & $7-10$ & Cross-sectional & 713 & $\begin{array}{l}\text { OV } 20.9, \text { OB } 9.8 \\
\text { Boys: OV } 18.5 \text {, OB } 6.9 \\
\text { Girls: OV } 23.3 \text {, OB } 12.9\end{array}$ \\
\hline Negash et $\mathrm{al}^{35 \mathrm{a}}$ & 2017 & South Africa, Western cape & $7-18$ & Cross-sectional & 1559 & $\begin{array}{l}\text { OV I5.6, OB } 7.3 \\
\text { Boys: OV } 9.4, \text { OB } 4.5 \\
\text { Girls: OV } 19.7 \text { OB } 9.1\end{array}$ \\
\hline Tathiah et $\mathrm{al}^{74 \mathrm{a}}$ & 2013 & South Africa, Nongoma, Ceza & $9-12$ & Secondary data & 963 & OV 9.0 OB 3.8 \\
\hline Truter et $\mathrm{al}^{94 \mathrm{a}}$ & 2010 & South Africa, Potchefstroom & $9-12$ & Cross-sectional & 280 & $\begin{array}{l}\text { OV 5.5, OB } 6.5 \\
\text { Boys: OV } 7.2, \text { OB } 2.5 \\
\text { Girls: OV } 8.3, \text { OB } 4.0\end{array}$ \\
\hline Armstrong et a $1^{95 a}$ & 2017 & South Africa, all 5 provinces & $6-13$ & Cross-sectional & 10,285 & $O V+O B \quad 15.4$ \\
\hline Puckree $96 \mathrm{~b}$ & 2011 & S.Africa, Kwazul-Natal & $10-12$ & Cross-sectional & 120 & OV 5.0 \\
\hline Yusuf et $\mathrm{al}^{36 \mathrm{a}}$ & 2013 & Nigeria, Kano & $13-18$ & Cross-sectional & 718 & OV 1.98, OB 0.84 \\
\hline Umar et $\mathrm{al}^{37 \mathrm{a}}$ & 2018 & Nigeria, Kano & $6-18$ & Cross-sectional & 720 & $\begin{array}{l}\text { OV } 8.9, \text { OB } 3.3 \\
\text { Boys: OV } 7.0, \text { OB } 3.0 \\
\text { Girls: OV } 10.8 \text {, OB } 3.6\end{array}$ \\
\hline $\begin{array}{l}\text { Kambonda \& } \\
\text { Sartorius }\end{array}$ & 2018 & Zimbabwe, Mashonaland & $6-12$ & Cross-sectional & 974 & OV 6.0, OB 7.7 \\
\hline Kyallo et a ${ }^{5 \text { lb }}$ & 2013 & Kenya, Nairobi & $9-14$ & Cross-sectional & 344 & $\begin{array}{l}\text { OV+OB combined } 19.0 \\
\text { Boys: OV+OB } 16.8 \\
\text { Girls: OV+OB } 21.0\end{array}$ \\
\hline Rapando et $\mathrm{al}^{52 \mathrm{~b}}$ & 2017 & Kenya, Langata, Nairobi & $14-18$ & Cross-sectional & 292 & $\begin{array}{l}\text { OV+OB } 17.8 \\
\text { Boys: OV+OB } 16.96 \\
\text { Girls: OV+OB } 20.59\end{array}$ \\
\hline Muthuri et $\mathrm{al}^{53 \mathrm{~b}}$ & 2014 & Kenya, Nairobi & $9-11$ & Cross-sectional & 563 & OV 14.4, OB 6.4 \\
\hline $\begin{array}{l}\text { Annan-Asare } \\
\text { et } \mathrm{al}^{39 \mathrm{e}}\end{array}$ & 2017 & Ghana, Accra metropolis & $11-15$ & Cross-sectional & 260 & $\begin{array}{l}\text { Boys: OV } 26.1 \text {, OB } 26.0 \\
\text { Girls: OV } 33.3 \text {, OB } 27.0\end{array}$ \\
\hline Musa et $\mathrm{al}^{5 \mathrm{a}}$ & 2012 & Nigeria, Bene & $9-16$ & Cross-sectional & 3240 & $\begin{array}{l}\text { adolescents: OV 9.7, OB } 1.8 \\
\text { children: OV } 18.3, \text { OB } 3.2\end{array}$ \\
\hline Wamba et $\mathrm{al}^{7 \mathrm{a}}$ & 2013 & Cameroon, Douala & $8-15$ & Cross-sectional & 2689 & OV 12.4, OB 1.9 \\
\hline $\begin{array}{l}\text { Van den Berg } \\
\text { et } \mathrm{al}^{40 \mathrm{~b}}\end{array}$ & 2014 & Lesotho, Maseru & 16 & Cross-sectional & 221 & $\begin{array}{l}\text { Boys: OV } 8.3 \\
\text { Girls: OV } 27.2\end{array}$ \\
\hline $\begin{array}{l}\text { Mohamed \& } \\
\text { Vuvor }^{6 b}\end{array}$ & 2012 & Ghana, Accra & $5-15$ & Cross-sectional & 270 & $\begin{array}{l}\text { OV I5.8 OB I0.9 } \\
\text { Boys: OV 16.7, OB } 7.2 \\
\text { Girls: OV I5.0, OB I5.0 }\end{array}$ \\
\hline Ofakunrin et $\mathrm{al}^{38 \mathrm{a}}$ & 2018 & Nigeria, Jos north central & $6-13$ & Cross-sectional & 600 & OV 10.3 OB 1.7 \\
\hline Sagbo et $a^{15 a}$ & 2018 & Togo, Lomé & $8-17$ & Cross-sectional & 634 & $\begin{array}{l}\text { OV 5.2, OB } 1.9 \\
\text { Boys: OV } 3.8 \\
\text { Girls: OV } 6.4\end{array}$ \\
\hline Nagwa et $a^{50 b}$ & 2011 & Sudan, Khartoum & $10-18$ & Cross-sectional & 1138 & $\begin{array}{l}\text { OV 10.8, OB } 9.7 \\
\text { Boys: OV } 9.9 \text { OB II.4 } \\
\text { Girls: OV 1 I.6, OB } 8.2\end{array}$ \\
\hline Salman et $\mathrm{al}^{49 \mathrm{c}}$ & 2010 & Sudan, Khartoum & $6-12$ & Cross-sectional & 304 & $\begin{array}{l}\text { OV I4.8, OB I0.5 } \\
\text { Boys: OV I I.8, OB } 5.9 \\
\text { Girls: OV I4.0, OB II.0 }\end{array}$ \\
\hline Hussein et $\mathrm{al}^{48 \mathrm{~b}}$ & 2018 & Northern Sudan, Argo & $6-14$ & Cross-sectional & 1223 & $\begin{array}{l}\text { OV 6.2, OB I.5 } \\
\text { Boys: OV 5.4, OB } 1.6 \\
\text { Girls: OV 7.0, OB I.5 }\end{array}$ \\
\hline
\end{tabular}

(Continued) 
Table I (Continued).

\begin{tabular}{|c|c|c|c|c|c|c|}
\hline Author & Year & Country, Region & $\begin{array}{l}\text { Age } \\
\text { (Years }\end{array}$ & Study Design & $\begin{array}{l}\text { Sample } \\
\text { (n) }\end{array}$ & $\begin{array}{l}\text { Prevalence of Overweight/ } \\
\text { Obesity (\%) }\end{array}$ \\
\hline Hussein ${ }^{46 c}$ & 2018 & Libya, Misurata & $6-11$ & Cross-sectional & 1000 & $\begin{array}{l}\text { OV I5.8, OB I2.4 } \\
\text { Boys: OV I5.4, OB I2.5 } \\
\text { Girls: OV 16.I, OB } 12.2\end{array}$ \\
\hline Sheriff ${ }^{47 e}$ & 2016 & Libya, Chennai & $12-18$ & Cross-sectional & 900 & $\begin{array}{l}\text { Boys: OV 10.0, OB } 2.9 \\
\text { Girls: OV 8.0, OB } 1.5\end{array}$ \\
\hline Taha \& Marawan ${ }^{42 c}$ & 2015 & Egypt, Menoufia & $8-12$ & Cross-sectional & 354 & $\begin{array}{l}\text { OV 19.5, OB } 23.7 \\
\text { Boys: OV+OB } 46.4 \\
\text { Girls: OV+OB } 53.6\end{array}$ \\
\hline Talat \& El-Shahat ${ }^{44 d}$ & 2015 & Egypt, Sharkia & $12-15$ & Cross-sectional & 900 & $\begin{array}{l}\text { OV 20.0, OB I0.7 } \\
\text { Boys: OV 20.1, OB } 10.4 \\
\text { Girls: OV 19.9, OB } 10.9\end{array}$ \\
\hline Badawi et $\mathrm{al}^{45 \mathrm{~d}}$ & 2013 & Egypt, Port Said city & $12-15$ & Cross-sectional & 852 & $\begin{array}{l}\text { OV } 17.7, \text { OB I3.5 } \\
\text { Boys OV I8.4, OB } 13.0 \\
\text { Girls OV I7.।, OB } 14.0\end{array}$ \\
\hline Hadhood et $\mathrm{al}^{43 \mathrm{~d}}$ & 2017 & Egypt, Sohag & $6-14$ & Cross-sectional & 711 & OV 16.5, OB 14.6 \\
\hline Mekonnen et $\mathrm{al}^{8 \mathrm{~b}}$ & 2018 & Ethiopia, Bahir Dar & $6-12$ & Cross-sectional & 616 & $\begin{array}{l}\text { OV+OB } 11.9 \\
\text { OV } 8.8, \text { OB } 3.1\end{array}$ \\
\hline Desalew et $\mathrm{al}^{4 / \mathrm{c}}$ & 2017 & Ethiopia, Dire dawa & $11-15$ & Cross-sectional & 448 & $\begin{array}{l}\text { OV 14.7, OB } 5.8 \\
\text { Boys: OV } 12.3 \text {, OB } 8.6 \\
\text { Girls: OV } 16.5 \text {, OB } 3.8\end{array}$ \\
\hline $\begin{array}{l}\text { Peltzer \& } \\
\text { Pengpid }^{55 a}\end{array}$ & 2011 & Ghana \& Uganda & $13-15$ & $\begin{array}{l}\text { National data } \\
\text { survey }\end{array}$ & 5613 & $\begin{array}{l}\text { Boys: OV+OB } 3.2 \\
\text { Girls: OV+OB } 10.4\end{array}$ \\
\hline Chebet et $\mathrm{al}^{54 \mathrm{~b}}$ & 2015 & Uganda, Kampala & $8-12$ & Cross-sectional & 958 & OV 32.3, OB 21.7 \\
\hline Mosha \& Fungo ${ }^{56 b}$ & 2010 & $\begin{array}{l}\text { Tanzania, Dar-es salaam and } \\
\text { Dodoma }\end{array}$ & $6-12$ & Cross-sectional & 428 & $\begin{array}{l}\text { OV } 5.8 \text {, OB } 6.4 \text { in } 6-9 \text { years } \\
\text { OV } 4.9 \text {, OB } 5.4 \text { in } 10-12 \text { years }\end{array}$ \\
\hline Muhihi et $\mathrm{al}^{58 \mathrm{a}}$ & 2013 & Tanzania, Dar-es salaam & $6-17$ & Cross-sectional & 446 & $\begin{array}{l}\text { OV } 9.8 \text { OB } 5.2 \\
\text { Boys; OV6.3 OB } 3.8 \\
\text { Girls; OVI3.I OB } 6.3\end{array}$ \\
\hline Mwaikambo et $\mathrm{al}^{59 \mathrm{a}}$ & 2015 & Tanzania, Dar-es salaam & $7-14$ & Cross-sectional & 1722 & $\begin{array}{l}\text { OV } 10.2, \text { OB } 4.5 \\
\text { Boys OV+OB comb } 14.9 \\
\text { Girls: OV+OB comb } 14.5\end{array}$ \\
\hline Pangani et $\mathrm{al}^{6 / \mathrm{b}}$ & 2016 & Tanzania, Dar-es salaam & $8-13$ & Cross-sectional & $|78|$ & $\begin{array}{l}\text { OV 15.9, OB } 6.7 \\
\text { Boys: OV I2.I, OB } 4.0 \\
\text { Girls: OV 18.7, OB } 8.0\end{array}$ \\
\hline Kimario ${ }^{60 a}$ & 2015 & Tanzania, Kilimanjaro & $10-12$ & Cross-sectional & 140 & OV+OB 20 \\
\hline Tluway et $\mathrm{al}^{57 \mathrm{a}}$ & 2018 & Tanzania, Manyara & $10-19$ & Cross-sectional & 619 & $O V+O B 9.2$ \\
\hline
\end{tabular}

Note: ${ }^{\mathrm{a}} \mathrm{OOTF},{ }^{\mathrm{b}} \mathrm{WHO},{ }^{\mathrm{c} C D C}$, ${ }^{\mathrm{d}} \mathrm{EGC}$ and NRC, e unspecified.

Abbreviations: CDC, Centre for Disease Control; EGC and NRC, Egyptian Growth Charts and National Research Centre; IOTF, International Obesity Task Force; OV, overweight; OB, obesity; WHO, World Health Organization.

and Google Scholar. Due to lack of enough knowledge and limited evidence on the contribution of home and school environment on children's food choices in African context a narrative review was proposed against other types of the systematic review. A narrative review is done when there is methodological limitations and therefore there is a need for future research on the topic of interest. ${ }^{32,33}$ This review includes articles published over the decade, from the 1st of January, 2008 to the 30th of June, 2018 with the exception of a few reports from "grey" literature which were considered beyond the specified period. Key search terms developed were used either singly and/or in combination. These terms included food environment, school environment, home environment, dietary habits, food choice, factors, school-aged children, overweight, obesity, developing countries, and Africa. After refining the inclusion and exclusion criteria, abstracts and full articles of all eligible studies were read. 


\section{Data Extraction}

Major findings/data on the prevalence of overweight and obesity in African school children are summarized in Table 1. Major findings of the articles on influence of home and school food environment on food choice were summarized in Table 2, with the following subheadings: name of the first author and year of publication, country, environment studied (home or school), study design and description of main findings of the study. Information from grey literature was also included in the description of studies.

\section{Results \\ Description of Included Studies}

Of the 343 articles identified 294 were excluded, finally, 49 studies and 5 reports "grey literature" were included in the review (Figure 1). About 39 studies investigated the prevalence of overweight and obesity in African countries, and 10 articles

Table 2 Summary of Studies on Influence of School and Home Environment on Children Food Choice in Selected African Countries

\begin{tabular}{|c|c|c|c|c|}
\hline Study & Country & Environment & Study Design & Description of Findings \\
\hline $\begin{array}{l}\text { Kalimbira \& Gondwe, } \\
2015^{62}\end{array}$ & Malawi & $\begin{array}{l}\text { School \& } \\
\text { Home }\end{array}$ & Cross- sectional & $\begin{array}{l}\text { Many school children }(>80 \%) \text { consume sugar-sweetened } \\
\text { beverages regularly, carbohydrate-rich foods, before going to } \\
\text { school, at school and after school. }\end{array}$ \\
\hline Brown et al, $2015^{63}$ & Botswana & $\begin{array}{l}\text { School \& } \\
\text { Home }\end{array}$ & Qualitative & $\begin{array}{l}\text { Parental control dictates what a child eats; eating out exposes } \\
\text { a child to junk foods; peer pressure influence on food choice; } \\
\text { energy-dense foods are readily available in school shops. }\end{array}$ \\
\hline Itatiro, $2014^{64}$ & Tanzania & School & Cross-sectional & $\begin{array}{l}\text { Food vendors around school environments formed the main } \\
\text { food suppliers, followed by school shops, canteens. Main } \\
\text { foods supplied were snacks and soft drinks, while fruits, } \\
\text { vegetables and dairy products were less available. }\end{array}$ \\
\hline Sedibe et al, $2014^{65}$ & South Africa & $\begin{array}{l}\text { School \& } \\
\text { Home }\end{array}$ & Qualitative & $\begin{array}{l}\text { Role of caregivers in preparing healthy foods through the } \\
\text { availability of home gardens; adolescent perception on healthy } \\
\text { foods; barriers to access healthy foods. }\end{array}$ \\
\hline Bekker et al, $2017^{66}$ & South Africa & School & Mixed method & $\begin{array}{l}\text { The presence of healthy food varieties in the school tuck shop } \\
\text { influenced a positive attitude and perceptions towards healthy } \\
\text { eating although unhealthy options should also be available. }\end{array}$ \\
\hline Abrahams et al, $2011^{67}$ & South Africa & School & Quasi-experiment & $\begin{array}{l}\text { Children who brought lunch boxes to school comprised of } \\
\text { healthy food options had lower BMI compared to children } \\
\text { who bought food items from school shops. }\end{array}$ \\
\hline Kupolati et al, $2017^{20}$ & South Africa & School & Qualitative & $\begin{array}{l}\text { Teachers perceived that nutrition education can influence } \\
\text { positive healthy eating habits in the school environment. }\end{array}$ \\
\hline Feeley \& Norris, $2014^{69}$ & South Africa & $\begin{array}{l}\text { School \& } \\
\text { Home }\end{array}$ & Cross-sectional & $\begin{array}{l}\text { Consumption of fast foods such as fried chips and sweetened } \\
\text { beverages at school, at home and around the community was } \\
\text { higher among adolescents (I7years old) compared to } \\
\text { consumption of confectionary and salty snacks in the urban } \\
\text { environment }\end{array}$ \\
\hline Faber et al, $2013^{68}$ & South Africa & School & Cohort & $\begin{array}{l}\text { School environment provides less options of health foods like } \\
\text { fruits and vegetables but more of unhealthy food items like } \\
\text { chips, sweets, chocolates and biscuits which are preferred by } \\
\text { children. }\end{array}$ \\
\hline Chan Sun et al, $2009^{27}$ & Mauritius & School & Cross-sectional & $\begin{array}{l}\text { Confectionaries and deep-fried foods, soft drinks and desserts } \\
\text { were most commonly sold (by more than } 75 \% \text { ) followed by main } \\
\text { meals from canteens and food vendors; healthy foods like dairy } \\
\text { products and fruits were also available }\end{array}$ \\
\hline
\end{tabular}

Abbreviation: BMI, body mass index. 


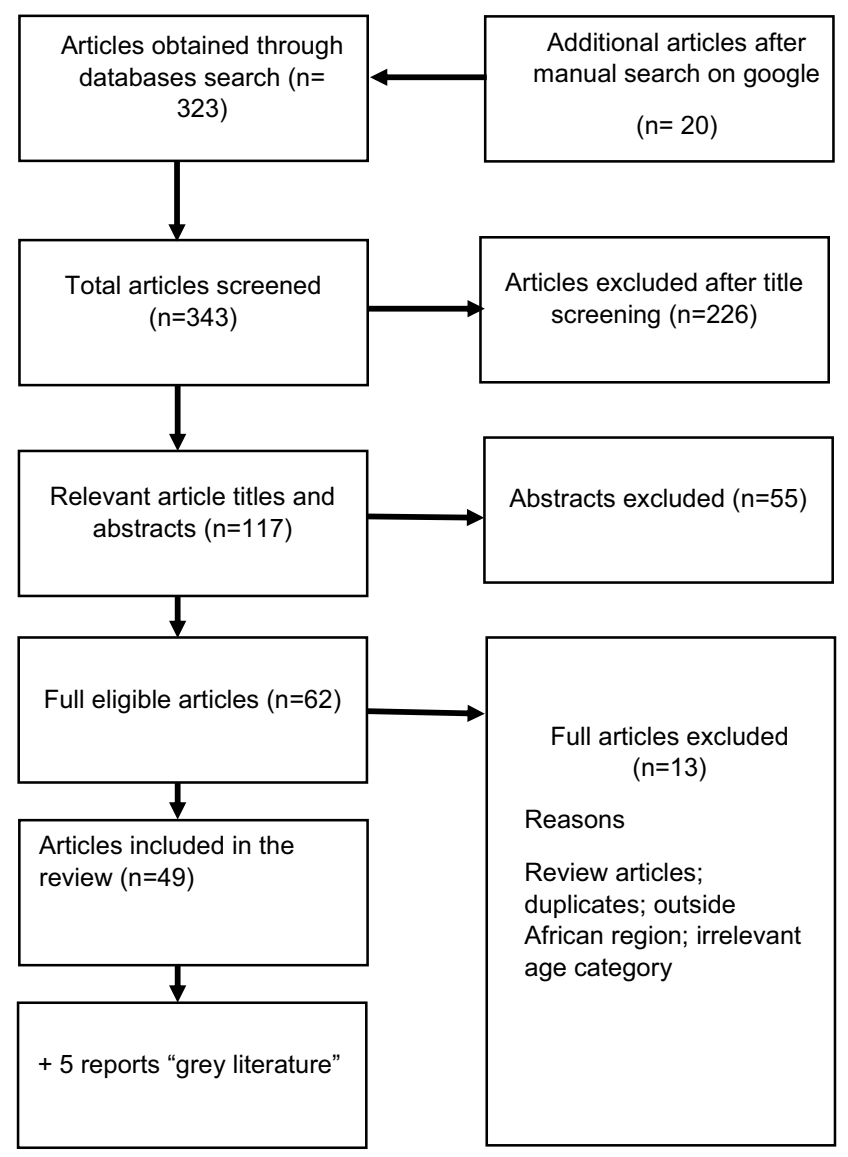

Figure I Flow chart of the selection process for inclusion of eligible studies.

reported on the influence of home and school food environment on school children's food choices. Grey literature provided insights on strategies for creating enabling healthy food environments except Global Nutrition report which provided data on the global prevalence of overweight and obesity in children and adolescents. Other reports were from World Health Organization (WHO), Food and Agriculture Organization (FAO) Tanzanian Ministry of Health, Global Agricultural Information Network. Thirty-six of the reviewed articles on overweight and obesity prevalence used a crosssectional study design, two studies used the analysis of secondary data and one study used longitudinal design. Details are presented in Table 1. Three out of ten articles (Table 2) on school and home environment used qualitative methods, four studies used a cross-sectional method, one of each article used a mixed-methods approach, a cohort and a quasi-experiment.

\section{Key Findings of This Review}

There is observed increase in overweight and obesity prevalence between studies and countries although there are notable variations.
Northern and eastern African regions had higher rates of overweight and obesity compared to southern and horn of Africa regions.

Most of the studies were cross-sectional and reported higher prevalence of overweight and obesity in girls than in boys.

Different cut-off values (WHO, IOTF, CDC) were used to define overweight and obesity which may cause variation in prevalence. Therefore interpretation of results needs a caution.

There is limited information on contribution of home and school food environment in children's food choice as well as link between food choice and obesity prevalence. Therefore, creating a research gap in this area.

Proposed strategies would shed some lights on creating enabling healthful food environment for school children in Africa.

\section{Overweight and Obesity Prevalence Among School Children in Africa}

Evidence from reviewed articles (Table 1) showed diverse trends of overweight and obesity among school children across African countries. In South Africa, prevalence varied considerably between $5 \%$ to $>20 \%$ across studies in different years. Studies reported in 2010 and 2011 showed a low prevalence than studies reported from 2014. Studies by $^{34,35,94}$ reported that girls were likely to be more obese than boys (Table 1). In Nigeria the combined prevalence for overweight and obesity ranged between $2.8 \%$ in $2013^{36}$ to $12.2 \%$ in $2018 .^{38}$ The prevalence of overweight and obesity was higher in children than in adolescents, ${ }^{5}$ also higher in girls than in boys. ${ }^{38}$ In Ghana, a study by AnnanAsare and colleagues ${ }^{39}$ found a higher prevalence in both girls and boys than earlier work of ${ }^{6}$ which reported lower rates of overweight and obesity, although girls were 2 times more likely to be obese than boys. In Cameroon, ${ }^{7}$ and Zimbabwe, ${ }^{4}$ the prevalence of overweight and obesity in children was $<15 \%$. A Low prevalence of overweight and obesity $\left(<6 \%\right.$ ) was reported in Togo. ${ }^{15}$ In Lesotho, one study reported that girls were found to be more overweight than boys. ${ }^{40}$ In Egypt the prevalence rate of overweight and obesity ranged between $31->40 \%$. In one study $^{42}$ girls were more overweight and obese than boys while other studies ${ }^{44,45}$ showed slight variations. In Libya, two studies showed a prevalence range of 9.5-28.2\%. Boys were more overweight and obese than girls ${ }^{47}$ and in the other study ${ }^{46}$ small variations were found. In Sudan, 
the prevalence of overweight and obesity ranged between $7.7-25.3 \%$, the prevalence was low in recent study ${ }^{48}$ compared to previous studies ${ }^{49,50}$ which was related to the high socioeconomic status of parents. ${ }^{50}$ In Ethiopia overweight and obesity prevalence ranged between $11.9-20.5 \%$. In these studies, boys were more obese than girls, but girls were more overweight. Moreover, in private school prevalence was significantly higher than in public schools. ${ }^{41}$ Surprisingly, a study done in 2018 showed a lower prevalence than a study reported in 2017.

In East Africa, evidence shows that childhood overweight and obesity trends have increased at an alarming rate. In Kenya, studies of ${ }^{5-53}$ found a high prevalence of overweight and/or obesity in which girls were more likely to be overweight/obese than boys and high in private schools than public schools, ${ }^{52}$ the prevalence range between these studies was $17.8-20.8 \%$ and there is slight variation over time. In Uganda, a prevalence of $>50 \%$ (overweight and obesity combined) was reported by. ${ }^{54}$ In a national survey of two countries (Uganda and Ghana), the prevalence of overweight and obesity in girls was significantly higher than in boys. ${ }^{55}$ Tanzania, like other East African countries, is not immune to the growing problem of overweight and obesity in school-children as reflected by studies done across the country (see Table 1). The prevalence range was between $9.2-22.6 \%$. Studies by $^{58,61}$ found that girls were more overweight and obese than boys, and is higher in private schools than in public schools. ${ }^{61}$ Also, a low prevalence was found in a study ${ }^{57}$ done in a rural area.

\section{Influence of School and Home Environment}

Ten African-based studies (six from the school environment and four from both school and home environment) investigated the contributions of school and home environments on children's food choices and dietary habits (see Table 2). Three studies ${ }^{20,65,66}$ revealed that perception and availability of healthy food options in the home and school environments can improve children's food choices. One study ${ }^{67}$ associated BMI with food consumption. It reported that children who brought lunch boxes to school had lower BMI than children who consumed foods purchased from school tuck shops. These shops are characterized by high energy-dense foods. Other studies ${ }^{27,62,64,68,69}$ revealed the presence of unhealthy food options in either home or school environment which promotes consumption of these foods by school children. Parents and peers were also found to dictate unhealthy food choices by school children. $^{63}$

\section{Discussion}

\section{Overweight and Obesity Prevalence in School Children}

Obesity has now reached epidemic levels in both developing and developed countries. ${ }^{56,61}$ Different studies in Africa have shown the increased prevalence in obesity from the lowest reported at 5\% to the highest at above $40 \%$ across the review period of 10 years. Only 4 studies reported a prevalence of less than $10 \%$ when overweight and obesity are combined and 35 studies combined prevalence was more than $10 \%$. This trend is almost similar to what was reported in developed countries and some other developing countries in the global south. For instance, in Latin America, more than 20\% of schoolchildren were obese ${ }^{70}$ and in San Diego, 26.6\% of children were overweight and obese. ${ }^{29}$ Similarly, high prevalence of overweight and obesity (39.7\%) were found in Mexican school children ${ }^{71}$ while $31 \%$ of Canadian, ${ }^{72} 36.6 \%$ of Saudi Arabian ${ }^{73}$ and $32 \%$ of American ${ }^{30}$ school children were reported to be overweight and obese. This review observed variation in overweight and obesity prevalence between studies and over time. Therefore, data on overweight and obesity are complex and confusing, this may be due to different contexts and age groups under investigation. Some evidence showed that cultural and environmental factors may explain variation in obesity data among study subjects. ${ }^{5,37,61}$ Cultural norms in Africa favor large/fat body sizes especially in girls and women, thus it could be a barrier to maintain healthy body weight. $^{104}$ The difference in socio-economic status also contributed to these variations, as children from higher Social Economic Status are reported to be more obese than children from lower SES. ${ }^{8,34,37,50}$ Another variation may be attributed to different cut-off values used to define overweight and obesity and study designs. ${ }^{15}$ For example, in a study with Iranian adolescent CDC reference values obtained a higher rate of obesity by $3.2 \%$ than IOTF reference values in children aged 12-15 years of both sexes. ${ }^{102}$ Similarly, in Saudi Arabian adolescents WHO reference values showed a higher rate of obesity (almost by $6 \%$ ), but lower rates of overweight (almost by $5 \%$ ) than IOTF. ${ }^{103}$ Children from urban areas were found to be more obese $^{43,75}$ than children from rural areas. ${ }^{57,74}$ Similarly, 
Zhang et al $2016^{75}$ found an increased risk of overweight and obesity in urban Chinese school children, which may be caused by a difference in lifestyle behaviors between rural and urban settings. Generally, most urban populations have sedentary lifestyles and increased consumption of high energy-dense foods. ${ }^{58,76}$ To great extent urbanization has greatly affected African food culture and resulted in a shift in dietary consumption ${ }^{97}$ which leads to increased consumption of westernized diets which are perceived as a symbol of affluence. ${ }^{104}$ Along with urbanization is characterized by motorized lifestyle and physical inactivity. ${ }^{104}$ Many studies across countries reported a higher prevalence of overweight and obesity in girls compared to boys. This may be attributed to differences in gender roles where boys are more active than girls. ${ }^{37}$ Boys spent adequate time in fieldwork while girls spend more time at home. ${ }^{41}$ Early-onset of menarche in girls is associated with an increase in body fat and body weight. ${ }^{57}$ Also, children below 10 years were more likely to be obese than children/adolescents above 10 years. ${ }^{5,45,56}$ This pattern may be attributable to faulty feeding during early childhood. Children from private schools were associated with higher obesity rates, and the possible explanation for this was, private school children were linked to high social-economic status thus easily adopting unhealthy food choices. ${ }^{41,52}$

\section{Home and School Food Environment}

There is limited information on the influence of home and school environments on school children's food choices and obesity linkages. However, reviewed studies have demonstrated that obesity is a significant health problem and provide direction for evidence-based strategies and interventions. This study found that positive perception in healthy foods would improve children's healthy food choices. This was also revealed by a study in Southern Appalachia that strict parental control have influence in healthy food choices by children regardless of the availability of unhealthy food alternatives in the home environment, ${ }^{30}$ this mighty influence healthy food choices during adolescence and adulthood. Some of the reviewed studies also found that unhealthy food options are readily available in African school environments as well as in the home environment, and children prefer to choose and consume these foods. These findings are similar to studies from other settings, Brazil, ${ }^{70}$ South Africa, ${ }^{77}$ India, ${ }^{19}$ San Diego. ${ }^{29}$ Only one study from South Africa linked BMI and food intake. This is in line with a study from Saudi
Arabian school children which found a positive association between increased intakes of sugar-sweetened carbonated beverages with an increase in BMI. ${ }^{73}$ Studies among Irish children ${ }^{21}$ and Vancouver Canada adolescents ${ }^{79}$ revealed that parents had the most significant control on child's food intake. In addition, parents have more influence on portion sizes to be offered to children, however, decision, motivation and parental feeding goals are not well understood. ${ }^{80}$ Presence of parents at home and their involvement in feeding practices influence role modeling, shape positive behavior change and modify available foods in the home environment. ${ }^{81}$. In addition to their presence at home, parents also are involved in family food preference, time allocation, prioritization of activities, preparation of food, skills, financial and health attributes. Children also are imitating these attributes. ${ }^{101}$ A study in Jordan revealed that peer influence associated significantly with disordered eating behavior among adolescents with respect to their body images. ${ }^{99}$ A recent systematic review of literature revealed that peers and siblings have both positive (healthy eating) and negative (unhealthy eating) influence on food choices of children. However, negative influence is most common. ${ }^{100}$

\section{Strategies for Creating Enabling Healthful Food Environment \\ Conducting Informative Research}

Effective implementation of optimal intervention strategies to prevent obesity in the African context needs sufficient evidence on current and periodic trends of obesity across countries. ${ }^{82}$ Knowledge about food choice and dietary habits data among African school children is inadequate, therefore, more consumer research on the school and home food environment are required. Studies in developing countries need to examine the role of local/informal food vendors and other sources of food like production and food donations on food choice. ${ }^{17}$ There is a need to focus on the penetration of supermarkets that offer highly processed food varieties. ${ }^{17}$ Nevertheless, before launching school-based interventions in low and middle-income countries, we need to establish culturally based evidence. This is because of differences in values, norms, customs, and environmental influences on food choices for children. The existing models from developed countries may not work in the African context. ${ }^{83}$ Barriers and facilitators influencing healthy eating behaviors in the home and school environment need to be thoroughly investigated as 
little research exist in this area. Context-specific schoolbased interventions, if implemented effectively, can improve the nutritional status of school children.

\section{Designing Social-Ecological Frameworks for Africa}

Apart from biophysical factors (genes, age, gender) the ecological perspective states that the physical environment has a direct link to obesity due to its influence on food choices.

The social-ecological perspective describes relationships between an individual and environment positing that individual behavior emerges from the interplay of multiple factors between the two entities. ${ }^{78}$ The social-ecological framework considers five levels of influence: Individual (knowledge, attitude, and self-concept); Interpersonal (family, peers, friends, social networks); Community (relationships between organizations); Organizational (organizations and social institutions); and Policy/enabling environment (national, state, local). At the individual level, school children need to receive nutrition education to equip them with appropriate knowledge to make informed healthy food choices and change their attitudes and skills to build self-efficacy. ${ }^{65,85}$ At the interpersonal/ family level, training of parents and modification of the home environment is required. It is also imperative to create awareness through health promotion campaigns targeting parents, households, and communities on a healthy diet and dietary diversity. Dietary diversity should promote the consumption of nutrient-dense culturally acceptable foods and minimize the consumption of processed foods. ${ }^{86}$ African communities should maximize development of diets that uses local food staffs. Parents have the role to model healthy eating habits and food choices to their children. Parents should be well informed on the outcome of poor dietary habits of their children and be motivated to become good examples. ${ }^{80}$ At the organization/school level, teachers are capacitated to deliver nutrition education and communication messages to pupils. Promotion/modification of school food policy/environment and creating resources for physical activity can easily be designed and implemented at the school level. National and local levels are obliged to set policies and laws that will promote the creation of a healthful enabling food environment. The development of ecological framework need to consider African culture. Socio-cultural beliefs has influence in nutrition matters of families since some foods are highly prized to complete a meal and these foods may have influence on weight changes. Some food taboos are related to particular foods, for example foods from animal origin. ${ }^{98}$ Issues related to food preparation, sharing, distribution, indigenous knowledge, attitudes and practices should be considered.

\section{Multisectoral Partnership/Coordination}

Prevention and/or management of overweight/obesity in children is a shared responsibility between different sectors. No single sector will address this complex, multifaceted problem. African member states should be willing to take responsibilities through preparation and enhancement of policies across all sectors. ${ }^{87}$ The health sector needs to initiate, implement, and innovate primary and secondary overweight/obesity preventive measures. The education sector needs to integrate and implement nutrition-related courses in primary school curriculum ${ }^{88}$ with content delivery predicated on the building of teachers' capacities to deliver nutrition education to children. The agriculture sector needs to emphasize on the production of local nutrient-dense foods at an affordable cost and the periodic revision of import trade policies. ${ }^{87}$ Food regulatory bodies are tasked to set and enforce import requirements and regulations to ensure that imported foods meet agreed quality standards. ${ }^{89}$ In addition, food and beverage industry need to focus on healthy product development, by reformulating nutrient-dense food categories to deliver better diets for all. Due to industrial development and economic changes many people have shifted their food habits from whole cereals, legumes, fruits and vegetables towards purchasing and consuming more processed foods and drinks. ${ }^{90}$ Therefore, this sector needs a high level of commitment in manufacturing healthy products that are affordable and available to all groups of consumers.

\section{Social Behavior Change Communication}

One of the most promising strategies to prevent childhood obesity is social behavior change communications. This strategy includes individual counseling, mass media campaigns, and education sessions. If these are targeted to relevant audiences, like school children, schools, nongovernmental organizations, and decision-makers, the expected outcomes may be achieved. ${ }^{32}$ An example of this approach is reflected in Tanzania's national nutrition social behavior change communication (SBCC) strategy which aims at raising awareness through an increase in knowledge, attitude, and skill training. It also aims at creating quality nutrition services that will favor the demand of consumers, other beneficiaries and increase access to quality communication materials, SBCC guidelines, protocols, and other tools to the district level. ${ }^{91}$ SBCC needs to be developed, pre- 
tested, and disseminated to the target population. A review of literature in developing countries showed success in integrating social behavior change communication interventions with nutritional specific programs. ${ }^{92}$ For example, a study conducted in Malawi used SBCC strategy in a supplementary feeding program and showed promising effect. ${ }^{93}$

\section{Conclusion}

This review found an increased and varied prevalence of overweight and obesity in school children up to above $40 \%$ across African countries in ten years period. However, the studies focusing on their linkages with home and school environment are scarce, therefore, this calls for more research attention and informed policy change in this area. High socio-economic status, female gender, urban residence and children in private schools associated significantly with increased prevalence of overweight/obesity in children. The presence of high energy-dense foods in school and home environments contribute to unhealthy dietary choices in school children. Most of the articles reviewed were methodologically limited as they involved "one-off" crosssectional design studies as opposed to longitudinal, case-control, and controlled randomized trials. However, some studies on food environment used qualitative approach, which is strong in highlighting the subjects' perceptions, ideas, and opinions. This review was restricted to school and home physical food environment, (availability and accessibility). Other components were not considered. It focused on a topic which, in most cases, receives low attention in nutrition research. This review was limited to 10 years period, and used English, a language conversant to authors and to the majority of readers.

\section{Abbreviations}

BMI, body mass index; DOAJ, Directory of Open Access Journals; FAO, Food and Agriculture Organization; CDC, Centre for Disease Control; EGC\&NRC, Egyptian Growth Charts \& National Research Centre; IOTF, International Obesity Task Force; OV, overweight; OB, obesity; SES, socio-economic status; SBCC, social behavior change communication; URT, United Republic of Tanzania; WHO, World Health Organization.

\section{Author Contributions}

All authors made a significant contribution to the reported work, from the conception, study design, execution, acquisition of data and interpretation. In all these areas; they took part in drafting, revising and critically reviewing the article; gave final approval of the version to be published; have agreed on the journal to which the article has been submitted; and agree to be accountable for all aspects of the work.

\section{Funding}

No funding was required to prepare this manuscript.

\section{Disclosure}

The authors declare that they have no conflicts of interest.

\section{References}

1. Rossouw HA, Grant CC, Viljoen M. Overweight and obesity in children and adolescents: the South African problem. S Afr J Sci. 2012;108(5/6):7. doi:10.4102/sajs.v108i5/6.907

2. Vepsäläinen H, Mikkilä V, Erkkola M, et al. Association between home and school food environments and dietary patterns among 9-11-year-old children in 12 countries. Int J Obes Supp. 2015;5 (S2):S66-S73. doi:10.1038/ijosup.2015.22

3. Pienaar AE. Prevalence of overweight and obesity among primary school children in a developing country: NW-CHILD longitudinal data of 6-9-yr-old children in South Africa. BMC Obes. 2015;2 (2):1-10. doi:10.1186/s40608-014-0030-4

4. Kambondo G, Sartorius B. Risk factors for obesity and overfat among primary school children in Mashonaland West Province, Zimbabwe. Int J Environ Res Public Health. 2018;15(249):1-14.

5. Musa DI, Toriola AL, Monyeki MA, Lawal B. Prevalence of childhood and adolescent overweight and obesity in Benue State, Nigeria. Trop Med and Int Health. 2012;17 (11):1369-1375. doi:10.1111/j.1365-3156.2012.03083.x

6. Mohammed H, Vuvor F. Prevalence of childhood overweight/ obesity in basic school in Accra. Ghana Med J. 2012;46 (3):124-127.

7. Wamba PCF, Oben JE, Cianflone K. Prevalence of overweight, obesity, and thinness in Cameroon urban children and adolescents. J Obes. 2013;2:1-9. doi:10.1155/2013/737592

8. Mekonnen T, Tariku A, Abebe SM. Overweight/obesity among school aged children in Bahir Dar City: cross sectional study. Riv Ital Pediatr. 2018;44(1):17. doi:10.1186/s13052-018-0452-6

9. Sahoo K, Sahoo B, Choudhury AK, Sofi NY, Kumar R, Bhadoria AS. Childhood obesity: causes and consequences. J Family Med Prim Care. 2015;4(2):187-192.

10. Development Initiatives. 2018 Global Nutrition Report: Shining a Light to Spur Action on Nutrition. Bristol, UK: Development Initiatives; 2018.

11. Lee YS. Consequences of childhood obesity. Ann Acad Med Singapore. 2009;38(1):75-81.

12. Center for Disease Control Report. Childhood Obesity Causes \& Consequences, Division of Nutrition, Physical Activity, and Obesity. National Center for Chronic Disease Prevention and Health Promotion, 2016. Available from: cdc.gov/obesity/child hood/causes.html. Accessed December 10, 2018.

13. Rankin J, Matthews L, Cobley S, et al. Psychological consequences of childhood obesity: psychiatric comorbidity and prevention. Adolesc Health Med Ther. 2016;14(7):125-146. doi:10.2147/AHMT.S101631

14. McKinnon RA, Reedy J, Morrissette MA, Lytle LA, Yaroch AL. Measures of the food environment, a compilation of the literature, 1990-2007. Am J Prev Med. 2009;36(Suppl 4):S124-S133. doi:10.1016/j.amepre.2009.01.012 
15. Sagbo H, Ekouevi DK, Ranjandriarison DT, et al. Prevalence and factors associated with overweight and obesity among children from primary schools in urban areas of Lomé, Togo. Public Health Nutr. 2018;21(6):1048-1056. doi:10.1017/S1368980017003664

16. Caspi CE, Sorensen G, Subramanian SV, Kawachi I. The local food environment and diet: A systematic review. Health Place. 2012;18(5):1172-1187. doi:10.1016/j.healthplace.2012.05.006

17. Turner C, Kadiyala S, Aggarwal A, et al. Concepts and Methods for Food Environment Research in Low and Middle-Income Countries. Agriculture, Nutrition and Health Academy Food Environments Working Group (ANH-FEWG). Innovative Methods and Metrics for Agriculture and Nutrition Actions (IMMANA) programme. London: London, UK; 2017.

18. Story M, Kaphingst KM, Robinson-O’Brien R, Glanz K. Creating healthy food and eating environments: policy and environmental approaches. Annu Rev Public Health. 2008;29(1):253-272. doi:10.1146/annurev.publhealth.29.020907.090926

19. Raychaudhuri M, Sanyal D. Childhood obesity: determinants, evaluation, and prevention. Indian J Endocr Metab. 2012;16 (Suppl 2):S192-4.

20. Kupolati MD, Gericke GJ, MacIntyre UE. Teachers' perceptions of school nutrition education's influence on eating behaviours of learners in the Bronkhorstspruit District. S Afr J Educ. 2015;35 (2):1-10. doi:10.15700/saje.v35n2a1049

21. Fitzgerald A, Heary C, Nixon E, Kelly C. Factors influencing the food choices of Irish children and adolescents: A qualitative investigation. Health Promot Int. 2010;25(3):289-298. doi:10.1093/heapro/daq021

22. El-Kassas G, Ziade F. The dual burden of malnutrition and associated dietary and lifestyle habits among Lebanese school age children living in orphanages in north Lebanon. J Nutr. 2017;2:4863431

23. Ochola S, Masibo PK. Dietary intake of schoolchildren and adolescents in developing countries. Ann Nutr Metab. 2014;64 (Suppl 2):24-40. doi:10.1159/000365125

24. Terry-McElrath YM, O’Malley PM, Delva J, Johnston LD. The school food environment and student BMI and food consumption: 2004 to 2007 National Data. J Adolesc Health. 2009;45(Suppl 3): S45-S56. doi:10.1016/j.jadohealth.2009.04.007

25. Katzmarzyk PT, Broyles ST, Champagne CM, et al. Relationship between soft drink consumption and obesity in 9-11 years old children in a multi-national study. Nutrients. 2016;8(12):770. doi: $10.3390 /$ nu8120770

26. Lytle LA, Sokol RL. Measures of the food environment: A systematic review of the field, 2007- 2015. Health Place. 2017;44:18-34. doi:10.1016/j.healthplace.2016.12.007

27. Chan Sun M, Lalsing Y, Subratty AH. Primary school food environment in Mauritius. Food Sci Nutr. 2009;39(3):251-259. doi:10.1108/00346650910957500

28. Boyland EJ, Kavanagh-Safran M, Halford JCG. Exposure to 'healthy' fast food meal bundles in television advertisements promotes liking for fast food but not healthier choices in children. Brit J Nutr. 2015;113(6):1012-1018. doi:10.1017/S0007114515000082

29. Couch SC, Glanz K, Zhou C, Sallis JF, Saelens BE. Home food environment in relation to children's diet quality and weigh status. J Acad Nutr Diet. 2014;114(10):1569-1579. doi:10.1016/ j.jand.2014.05.015

30. Wang L, Dalton WT, Schetzina KE, Fulton-Robinson H, Holt N, Ho A. Home food environment, dietary intake, and weight among overweight and obese children in Southern Appalachia. Southern M J. 2013;106(10):550-557. doi:10.1097/SMJ.000000000000 0008

31. Russell CG, Worsley A, Liem DG. Parents' food choice motives and their associations with children's food preferences. Public Health Nutr. 2014;18(6):1018-1027. doi:10.1017/S13689800140 01128
32. Bundara N, Mwanri L, Masika J. Addressing childhood undernutrition in Tanzania: challenges and opportunities. AJFAND. 2013;13(1):7288-7306. doi:10.18697/ajfand.56.12105

33. Ferrari R. Writing narrative style literature reviews. Medical Writing. 2015;24(4):230-235. doi:10.1179/2047480615Z.000000000329

34. Baard ML, McKersie J. Obesity in 7-10-year-old children in urban primary schools in Port Elizabeth. S Afr J SM. 2014;26 (2):55-58. doi:10.7196/sajsm.551

35. Negash S, Matsha TE, Agyemang C, Peer N, Erasmus RT, Kengne AP. Differential prevalence and associations of overweight and obesity by gender and population group among school learners in South Africa: a cross-sectional study. BMC Obes. 2017;4:29. doi:10.1186/s40608-017-0165-1

36. Yusuf SM, Mijinyawa MS, Musa BM, Gezawa ID, Uloko AE. Overweight and Obesity among Adolescents in Kano, Nigeria. $J$ Metabolic Synd. 2013;2(1):1-5.

37. Umar IU, Kakale IM, Gwarzo GD, Muutassim I. Prevalence of childhood and adolescent overweight and obesity in Kano State, Nigeria. EC Paediatrics. 2018;7(4):231-238.

38. Ofakunrin AOD, Obayomi JI, Afolaranmi TO, et al. Prevalence of overweight and obesity among school-age children in Jos, North Central, Nigeria. IJBR. 2018;9(6):208-213.

39. Annan-Asare J, Asante M, Amoah AGB. Obesity and its correlates among junior high school children in the Accra Metropolis. J Nutr Health Sci. 2017;4(2):1-10.

40. Van den Berg VL, Seheri L, Raubenheimer J. Body mass index of 16-year olds in urban Maseru, Lesotho. Afr J Prm Health Care Fam Med. 2014;6(1):14.

41. Desalew A, Mandesh A, Semahegn A. Childhood overweight, obesity and associated factors among primary school children in dire dawa, eastern Ethiopia; a cross-sectional study. BMC Obes. 2017;4(1):20. doi:10.1186/s40608-017-0156-2

42. Taha AA, Marawan HM. Socio-behavioral determinants of overweight and obesity in Egyptian primary school children. J Child Adolesc Behav. 2015;3:236. doi:10.4172/2375-4494.1000236

43. Hadhood SESA, Ali RAE, Mohamed MM, Mohammed ES. Prevalence and correlates of overweight and obesity among school children in Sohag, Egypt. Open J Gastroenterol. 2017;7 (02):75-88. doi:10.4236/ojgas.2017.72009

44. Talat MA, El Shahat E. Prevalence of overweight and obesity among preparatory school adolescents in Urban Sharkia Governorate, Egypt. Gaz Egypt Pediatr Assoc. 2016;64 (1):20-25. doi:10.1016/j.epag.2015.11.004

45. Badawi NE, Barakat AA, El Sherbini SA, Fawzy HM. Prevalence of overweight and obesity in primary school children in Port Said city, Egypt. Gaz Egypt Pediatr Assoc. 2013;61(1):31-36. doi:10.1016/j.epag.2013.04.007

46. Hussein AE. Overweight and obesity among primary school children in misurata city-libya: prevalence and associated risk factors. Int J Pediat Health Care Adv. 2018;5(2):74-78.

47. Sheriff DSA. Perspective on childhood obesity in general and libya in particular. AJPNMS. 2016;04(05):52-64.

48. Hussein MD, Alonazi NA, Mohamed S. Prevalence of obesity, overweight, underweight and stunting among school children in Argo city, Northern Sudan. Sudan J Paediatr. 2018;18(2):15-19. doi:10.24911/SJP.106-1544799078

49. Salman Z, Kirk GD, DeBoer MD. High rate of obesity-associated hypertension among primary schoolchildren in Sudan. Int J Hypertens. 2011;5. doi:10.4061/2011/629492.

50. Nagwa M, Elhussein A, Azza M, Abdulhadi NH. Alarming high prevalence of overweight/obesity among Sudanese children. Eur J Clin Nutr. 2011;65(3):409-411. doi:10.1038/ejcn.2010.253

51. Kyallo F, Makokha A, Mwangi AM. Overweight and obesity among public and private primary school children in Nairobi, Kenya. Health. 2013;5(83A):85-90. doi:10.4236/health.2013.58 A3012 
52. Rapando C, Nyagero J, Wakhu F. Feeding Habits associated with overweight and obesity amongst secondary school students in private and public schools in langata nairobi Kenya. IJSRP. 2017;7(5):498-505.

53. Muthuri SK, Wachira LM, Onywera VO, Tremblay MS. Correlates of objectively measured overweight/obesity and physical activity in Kenyan school children: results from ISCOLE-Kenya. BMC Public Health. 2014;14:436. doi:10.1186/ 1471-2458-14-436

54. Chebet M, Nsibambi C, Otala J, Goon DT. Prevalence of overweight and obesity among primary school children in Kampala central, Uganda. AJPHERD. 2014;20(4):1365-1378.

55. Peltzer K, Pengpid S. Overweight and obesity and associated factors among school-aged adolescents in Ghana and Uganda. Int $J$ Environ Res Public Health. 2011;8(10):3859-3870. doi:10.3390/ijerph8103859

56. Mosha TCE, Fungo S. Prevalence of overweight and obesity among children aged 6-12 years in Dodoma and Kinondoni Municipalities, Tanzania. Tanzan J Health Res. 2010;12 (1):1-13. doi: $10.4314 /$ thrb.v12i1.56202

57. Tluway FD, Leyna GH, Mmbaga EJ. Magnitude and factors associated with overweight and obesity among adolescents in semi-rural area of Babati District, Tanzania. Tanzan J Health Res. 2018;20(2):1-9.

58. Muhihi AJ, Mpembeni RNM, Njelekela MA, et al. Prevalence and determinants of obesity among school children in Dar es Salaam, Tanzania. Arch Public Heal. 2013;71(26):1-8.

59. Mwaikambo SA, Leyna GH, Killewo J, Simba A, Puoane T. Why are primary school children overweight and obese? A cross sectional study undertaken in Kinondoni district, Dar-es-Salaam. BMC Public Health. 2015;15(1269):1-10. doi:10.1186/s12889-015-2598-0

60. Kimario JT. Prevalence of Obesity and Overweight Among School Children in Moshi Municipality, Kilimanjaro, Tanzania [Dissertation]. Ghent: University of Ghent; 2015.

61. Pangani IN, Kiplamai FK, Onwera VO, Onywera VO. Prevalence of overweight and obesity among primary school children aged 8-13 in Dar-es-salaam City, Tanzania. Adv Prev Med. 2016;2016:1-6. doi:10.1155/2016/1345017

62. Kalimbira A, Gondwe E. Consumption of sweetened beverages among school-going children in a densely populated township in Lilongwe, Malawi. Malawi Med J. 2015;27(2):55-59. doi:10.4314/mmj.v27i2.5

63. Brown C, Shaibu S, Maruapula S, Malete L, Compher C. Perceptions and attitudes towards food choice in adolescents in Gaborone, Botswana. Appetite. 2015;95:29-35. doi:10.1016/j. appet.2015.06.018

64. Itatiro J. The Association of School Food Environment with Eating Habits of School Going Adolescents in Tanzania [Dissertation]. Ghent: University of Ghent; 2014.

65. Sedibe MH, Pisa PT, Feeley AB, Pedro TM, Kahn K, Norris SA. Dietary habits and eating practices and their association with overweight and obesity in rural and urban black South African adolescents. Nutrients. 2018;10(145):1-18. doi:10.3390/nu10020145

66. Bekker F, Marais M, Koen N. The provision of healthy food in a school tuck shop: does it influence primary-school students' perceptions, attitudes and behaviors towards healthy eating? Public Health Nutr. 2017;20(7):1257-1266. doi:10.1017/S13689 80016003487

67. Abrahams Z, de Villiers A, Steyn NP, et al. What's in the lunchbox? Dietary behaviour of learners from disadvantaged schools in the Western Cape, South Africa. Public Health Nutr. 2011;14 (10):1752-1758. doi:10.1017/S1368980011001108

68. Faber M, Laurie S, Maduna M, Magudulela T, Muehlhoff E. Is the school food environment conducive to healthy eating in poorly resourced South African schools? Public Health Nutr. 2013;17(6):1214-1223. doi:10.1017/S1368980013002279
69. Feeley AB, Norris SA. Added sugar and dietary sodium intake from purchased fast food, confectionery, sweetened beverages and snacks among Sowetan adolescents. S Afr J CH. 2014;8 (3):88-91. doi:10.7196/sajch.678

70. Corvalán C, Garmendia ML, Jones-Smith J, et al. Nutrition status of children in Latin America. Obes Rev. 2017;18(Suppl 2):7-18. doi:10.1111/obr.12571

71. Barquera S, Campirano F, Bonvecchio A, Hernández-Barrera RAJ, Popkin BM. Caloric beverage consumption patterns in Mexican children. Nutr J. 2010;9(47):1-10. doi:10.1186/1475-2891-9-47

72. Vine MM, Elliott SJ. Examining local-level factors shaping school nutrition policy implementation in Ontario, Canada. Public Health Nutr. 2013;17(6):1290-1298. doi:10.1017/ S1368980013002516

73. Collison KS, Zaidi MZ, Subhani SN, Al-Rubeaan K, Shoukri M, Al-Mohanna FA. Sugar-sweetened carbonated beverage consumption correlates with BMI, waist circumference, and poor dietary choices in school children. BMC Public Health. 2010;10 (1):234. doi:10.1186/1471-2458-10-234

74. Tathiah N, Moodley I, Mubaiwa V, Denny L, Taylor M. Overweight, obesity, underweight and stunting in female primary school learners in rural KwaZulu-Natal, South Africa. S Afr Med J. 2013;103(10):718-723. doi:10.7196/SAMJ.6922

75. Zhang N, Bécares L, Chandola T. Patterns and determinants of double-burden of malnutrition among rural children: evidence from China. PLoS One. 2016;11(7):e0158119. doi:10.1371/journal.

76. Kurnia P, Wardhani DTK, Hariyani R. Consumer attitudes, nutrition knowledge and use of nutrition information on the labels of packed drinks among adolescents in Surakarta, Indonesia. Int Conf Health Well Being. 2016;253-264.

77. De Villiers A, Faber M. The school food environment: shaping the future health of the nation. S Afr J Clin Nutr. 2015;28(1):4-5. doi:10.1080/16070658.2015.11734518

78. Gupta N, Goel K, Shah P, Misra A. Childhood obesity in developing countries: epidemiology, determinants and prevention. Endocr Rev. 2012;33(1):48-70. doi:10.1210/er.2010-0028

79. Watts AW, Barr SA, Hanning RM, Lovato CY, Mâsse LC. The home food environment and associations with dietary intake among adolescents presenting for a lifestyle modification intervention. BMC Nutr. 2018;4(1):3. doi:10.1186/s40795-018-0210-6

80. Scaglioni S, Arrizza C, Vecchi F, Tedeschi S. Determinants of children's eating behavior. Am J Clin Nutr. 2011;94 (suppl):2006S-11S. doi:10.3945/ajen.110.001685

81. Reicks M, Banna J, Cluskey M, et al. Influence of parenting practices on eating behaviors of early adolescents during independent eating occasions: implication for obesity prevention. Nutrients. 2015;7:8783-8801.

82. Adom T, Puoane T, De Villiers A, Kengne AP. Prevalence of obesity and overweight in African learners: A protocol for systematic review and meta-analysis. BMJ Open. 2017;7:e13538. doi:10.1136/bmjopen-2016-013538

83. Verstraeten R, Van Royen K, Ochoa-Avilès A, et al. A conceptual framework for healthy eating behavior in Ecuadorian adolescents: A qualitative study. PLoS One. 2014;9(1):e87183. doi:10.1371/ journal.pone.0087183

84. Golden SD, Earp JAL. Social ecological approaches to individuals and their contexts: twenty years of health education \& behavior health promotion interventions. Health Educ Behav. 2012;39(3):364-372.

85. Oldewage-Theron WH, Napier CE. Nutrition education tools for primary school children in the Vaal region. Dev South Afr. 2011;28(2):283-292. doi:10.1080/0376835X.2011.570075

86. Hoffman D, Cacciola T, Barrios P, Simon J. Temporal changes and determinants of childhood nutritional status in Kenya and Zambia. J Health Popul Nutr. 2017;36(1):27. doi:10.1186/ s41043-017-0095-z 
87. World Health Organization. Report of the Commission on Ending Childhood Obesity. Geneva, SWZ: WHO document Production Services; 2016.

88. Food and Agriculture Organization. Nutrition education in primary schools. The activities. Notes for facilitators and workshop organizers. Food and Nutrition Division. 2005;2:1-32.

89. Global Agricultural Information Network. Food and Agricultural Import Regulations and Standards - Narrative. FAIRS Country Report-Tanzania; 2016.

90. Alejandra NM, Paula CM, Patricia AM. Study of nutrition habits in primary school students. J Clin Nutr Diet. 2016;2(4):1-5. doi:10.4172/2472-1921.100026

91. United Republic of Tanzania. National Nutrition Social and Behavior Change Communication Strategy July 2013 June 2018;2020. Tanzania: Ministry of Health and Social Welfare.

92. Kennedy E, Stickland J, Kershaw M, Biadgilign S. Impact of social and behavior change communication in nutrition specific interventions on selected indicators of nutritional status. J Hum Nutr. 2018;2(1):34-46.

93. Wilner L, Suri DJ, Langlois BK, Walton SM, Rogers BL. Effective delivery of social and behavior change communication through a Care Group model in a supplementary feeding program. J Health Popul Nutr. 2017;36(1):34. doi:10.1186/s41043-0170111-3

94. Truter L, Pienaar AE, Du Toit D. Relationships between overweight, obesity and physical fitness of nine- to twelve-year-old South African children. S Afr Fam Pract. 2010;52(3):227-233. doi:10.1080/20786204.2010.10873979

95. Armstrong MEG, Lambert MI, Lambert EV. Relationships between different nutritional anthropometric statuses and health-related fitness of South African primary school children. Ann Hum Biol. 2017;44(3):208-213. doi:10.1080/03014460. 2016.1224386
96. Puckree T, Pillay NP, Naidoo T. Underweight and overweight in primary school children in eThekwini district in KwaZulu-Natal, South Africa. Af J Prim Heal Care Fam Med. 2011;3(1):1-6.

97. Oniang'o RK, Mutuku JM, Malaba SJ. Contemporary African food habits and their nutritional and health implications. Asia Pacific J Clin Nutr. 2003;12(3):231-236.

98. Sahoo K, Sahoo B, Choudhury AK, Sofi NY, Kumar R, Bhadoria AS. Childhood obesity: causes and consequences. J Family Med Prim Care. 2015;4(2):187-192. doi:10.4103/ 2249-4863.154628

99. Al-sheyab NA, Gharaibeh T, Kheirallah K. Relationship between peer pressure and risk of eating disorders among adolescents in jordan. J Obes. 2018;8:154.

100. Ragelienè T, Grønhøj A. The influence of peers' and siblings' on children's and adolescents' healthy eating behavior. A systematic literature review. Appetite. 2020;148:104592. doi:10.1016/j. appet.2020.104592.

101. Holsten JE, Deatrick JA, Kumanyika S, Pinto-Martin J, Charlene W. Compher, Children's food choice process in the home environment. A qualitative descriptive study. Appetite. 2012;58(1):64-73. doi:10.1016/j.appet.2011.09.002

102. Hajian-Tilaki K, Heidari BA. Comparison between international obesity task force and centre for disease control references in assessment of overweight and obesity among adolescents in babol, Northern Iran. Int J Prev Med. 2013;4(2):226-232.

103. Alqahtan N, Scott J. Childhood Obesity Estimates Based on WHO and IOTF Reference Values. J Obes Weight Loss Ther. 2015;5(1). doi:10.4172/2165-7904.1000249

104. Neupane S, Prakash KC, Doku DT. Overweight and obesity among women: analysis of demographic and health survey data from 32 Sub-Saharan African Countries. BMC Public Health. 2016;16(1):30. doi:10.1186/s12889-016-2698-5

\section{Publish your work in this journal}

Pediatric Health, Medicine and Therapeutics is an international, peerreviewed, open access journal publishing original research, reports, editorials, reviews and commentaries. All aspects of health maintenance, preventative measures and disease treatment interventions are addressed within the journal. Practitioners from all disciplines are invited to submit their work as well as healthcare researchers and patient support groups. The manuscript management system is completely online and includes a very quick and fair peer-review system. Visit http://www.dovepress.com/testimonials.php to read real quotes from published authors. 